EISSN: 2706-7955 ISSN: 2077-4605

DOI: $10.36632 /$ mejar/2021.10.2.36

Journal homepage: www.curresweb.com

Pages: 508-518

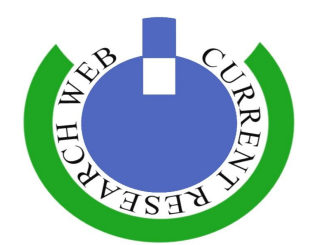

\title{
Effect of Different Egyptian Planting Location and Irrigation Water Salinity Level on Gypsophilla Plants Tolerance
}

\section{Magdy Azmy Barsoom¹, Georgina W. Rizk² and Zakrya B. Mohamed ${ }^{3}$}

${ }^{l}$ Ornamental Plants and Landscape Research Department, Horticulture Research Institute, A.R.C., Giza, Egypt

${ }^{2}$ Botanical garden Research Department, Horticulture Research Institute, A.R.C., Alexandria, Egypt

${ }^{3}$ Ornamental Plants and Landscape Research Department, El-Mataena Research Station, A.R.C., Luxor, Egypt

\author{
Received: 18 March $2021 \quad$ Accepted: 25 April $2021 \quad$ Published: 30 April 2021
}

\begin{abstract}
The experimental trial was consummated at three locations (Luxor, Giza and Alexandria) during 2015/2016 and 2016/2017 seasons to investigate the effect of the different planting locations in Egypt, combined with the effect of different salinity treatments on growth, flowering and chemical constituents of the newly formed plant of Gypsophila elegans in order to achieve higher productivity even under conditions of salinity stress to reduce the consumption of fresh water in a wide temperature range and different relative humidity. The results emphasized that Luxor location was the best for improving all plant parameters in both seasons. On the other hand, salinity treatments differed in their effects on plant traits, where the treatment of $\mathrm{CaCl}_{2} 1 \mathrm{~g} /$ plant was the best for improving the morphological characters and chemical constituents of the plant in the two seasons. The opposite was right for the effect on proline content which gave the lowest level compared with that gained from the other treatments used in the two seasons. From the aforementioned results, it could be recommended to plant Gypsophila elegans under the condition of Luxor with the addition of $\mathrm{CaCl}_{2}$ at $1 \mathrm{~g} / \mathrm{plant}$.
\end{abstract}

Keywords: Gypsophila elegans, planting location, plant quality, salinity.

\section{Introduction}

Baby's breath (Gypsophila elegans) is the herbaceous perennial. It has branching stems bearing clouds of tiny, white flowers. It forms mounds that reach approximately four feet in width and height. The plant prefers dry, sandy, stony, often calcareous soils. The genus name gypsophila translator to "chek-loving" but it can grow on a variety of soils and can survive wide variations in temperature and moisture. It is resistance to drought, wind and blown sand. It has a woody taproot that can penetrate the soil to 4 meters (BMCA, 2015) allowing the plant to overwinter in cold climates (Darwent, 1975). New shoots arise from the rootstock in the spring. The species name "elegans" refers to the inflorescence, which has many branched. The common name "baby's breath refers to the cloud-like appearance of the plant at flowering Baby's breath is a common flower found in ornamental bouquets and is raised primarily for the florist trade. The fruit of baby's breath is a small (1 to $2 \mathrm{~mm}$ ), disk of bean-shaped capsule, red brown to black in color. Baby's breath was widely introduced as an ornamental plant and florist crop in North America. It grows well in response to human disturbance and is found as the widespread weeds in areas such as grassland, pastures and sandunes (Pringle, 2005). It is difficult to remove once mature due to its deep tap root. Heavy grazing and moving prior to flowering reduces seed production. However, those measures will not kill existing plants (BMCA, 2015).

Thus, this study was the result of achieving the highest productivity and quality of Gypsophila elegans plant in case of cultivation under conditions of salinity stress or to rationalize the consumption of fresh water in a wide temperature range and different relative humidity.

Corresponding Author: Magdy Azmy Barsoom, Ornamental Plants and Landscape Research Department, Horticulture Research Institute, A.R.C., Giza, Egypt 


\section{Materials and Methods}

The experimental trial was consummated at three locations during the two successive seasons (2015/2016 , 2016/2017) with the aim to investigate the effect of planting locations (Luxor, Giza and Alexandria) on growth, flowering and chemical constituents of the newly formed plants of Gypsophila elegans under the different conditions of Egypt combined with the effect of different treatments of salinity.

\section{Materials}

Seeds of Gypsophila elegans were used in the two successive seasons.

Plastic pots of $20 \mathrm{~cm}$ diameter filled with about $3.5 \mathrm{~kg}$ of the different growing media used in the different locations (Luxor, Giza and Alexandria).

Physical and chemical properties of the used soil are presented in Table (a).

Table a: Chemical properties the used soil

\begin{tabular}{llllllllllll}
\hline & Alex & Giza & Luxor & $\begin{array}{c}\text { Cations } \\
(\mathbf{m e q} / \mathbf{l})\end{array}$ & Alex & Giza & Luxor & $\begin{array}{c}\text { Antions } \\
(\mathbf{m e q} / \mathbf{l})\end{array}$ & Alex & Giza & Luxor \\
\hline $\mathbf{N \%}$ & 1.03 & 1.224 & 1.802 & $\mathrm{Na}^{+}$ & 1.54 & 1.190 & 1.00 & $\mathrm{HCO}_{3}^{--}$ & 1.82 & 1.30 & 1.50 \\
$\mathbf{P \%}$ & 0.013 & 0.038 & 0.061 & $\mathrm{Ca}^{++}$ & 0.94 & 1.02 & 1.06 & $\mathrm{SO}^{-}$ & 0.69 & 0.30 & 1.20 \\
$\mathbf{K} \%$ & 0.96 & 0.75 & 0.525 & $\mathrm{Mg}^{++}$ & 0.923 & 0.802 & 0.50 & $\mathrm{Cl}^{-}$ & 2.16 & 1.45 & 1.18 \\
$\mathbf{p H}$ & 7.7 & 7.8 & 7.84 & & & & & & & & \\
$\mathbf{E . C . ~ d S / m ~}$ & 1.18 & 1.12 & 1.06 & & & & & & & & \\
Organic matter \% & 0.33 & 0.23 & 0.63 & & & & & & & & \\
\hline
\end{tabular}

Table b: The average temperature and relative humidity in Alexandria, Giza and Luxor

\begin{tabular}{lcccccccccccc}
\hline & \multicolumn{3}{c}{ September (1-15) } & \multicolumn{3}{c}{ September (16-30) } & \multicolumn{3}{c}{ October (1-15) } & \multicolumn{3}{c}{ October (16-31) } \\
\cline { 2 - 12 } & Alex & Giza & Luxor & Alex & Giza & Luxor & Alex & Giza & Luxor & Alex & Giza & Luxor \\
\hline $\begin{array}{l}\text { Temperature } \\
\text { Relative }\end{array}$ & 29 & 35 & 39 & 30 & 34 & 38 & 27 & 30 & 36 & 25 & 28 & 32 \\
humidity\% & 80 & 70 & 40 & 80 & 75 & 35 & 85 & 75 & 30 & 75 & 65 & 40 \\
\hline
\end{tabular}

\section{Procedure}

Seedlings of Gypsophila elegans were planted on September 3rd in both seasons in plastic pots of $20 \mathrm{~cm}$ diameter (one plant each). They were lift to grow under open field conditions, and irrigated with $250 \mathrm{ml} /$ pot 3 times weekly until the flowering stage with concentrations salt treatment as control without salt addition, $\mathrm{NaCl}(1,2,3,4 \mathrm{~g} / \mathrm{l}), \mathrm{CaCl}_{2}(1,2,3,4 \mathrm{~g} / \mathrm{l})$ and $\mathrm{NaCl}+\mathrm{CaCl}_{2}(0.5+0.5,1+1,1.5+1.5$ and $2+2 \mathrm{~g} / \mathrm{l}$ ) for each plant respectively. The plants were arranged in a factorial experiment in a randomized complete design with three replicates. The main plot represented planting location, whereas sub plot represented salinity treatments. Every experimental unit contained 4 plants and every treatment was represented by 12 plants.

Data were recorded on plant height $(\mathrm{cm})$, number of leaves/plant, number of branches, fresh and dry weights of leaves $(\mathrm{g})$, stem diameter $(\mathrm{cm})$, number of days from planting to flowering, number of flowers/plant.

Chemical constituents of the leaves: chlorophyll a, chlorophyll b, carotenoids (mg/g f.w.) and proline (mg/100g d.w.).

Regular agricultural processes practices were carried out wherever the plants needed.

Photosynthetic pigments content chlorophyll $(\mathrm{a}, \mathrm{b})$ and carotenoides $(\mathrm{mg} / \mathrm{g}$ f.w.) were determined according to the methods of Saric et al., (1967). (1973).

Free proline content (mg/100g d.w.) in the leaves was determined according to Bates et al.,

Data were statistically analyzed using SAS program (1994) and means were compared by L.S.D. method according to Snedecor and Cochran (1980). 


\section{Results}

\section{Effect on vegetative growth characters:}

a. Plant height:

Data exhibited in Table (1) revealed the prevalence of planting Gypsophila under Luxor location in both seasons, followed by Giza location for increasing those plants height in the two seasons. However, the shortest plant was a result of plants grown Alexandria location. The effect of the different treatments of salinity considerably varied as shown in Table (1), where the treatment of $\mathrm{CaCl}_{2}$ at $1 \mathrm{~g} /$ plant gave the utmost highest value in the two seasons. In the matter of the interactions, data revealed the superiority of plants grown under Luxor location and treated with $\mathrm{CaCl}_{2}$ at $1 \mathrm{~g} / \mathrm{p}$ in the two seasons.

Table 1: Effect of different types of salinity under different location on plant height (cm) of Gypsophilla elegans during the two seasons (2016/2017 and 2017/2018)

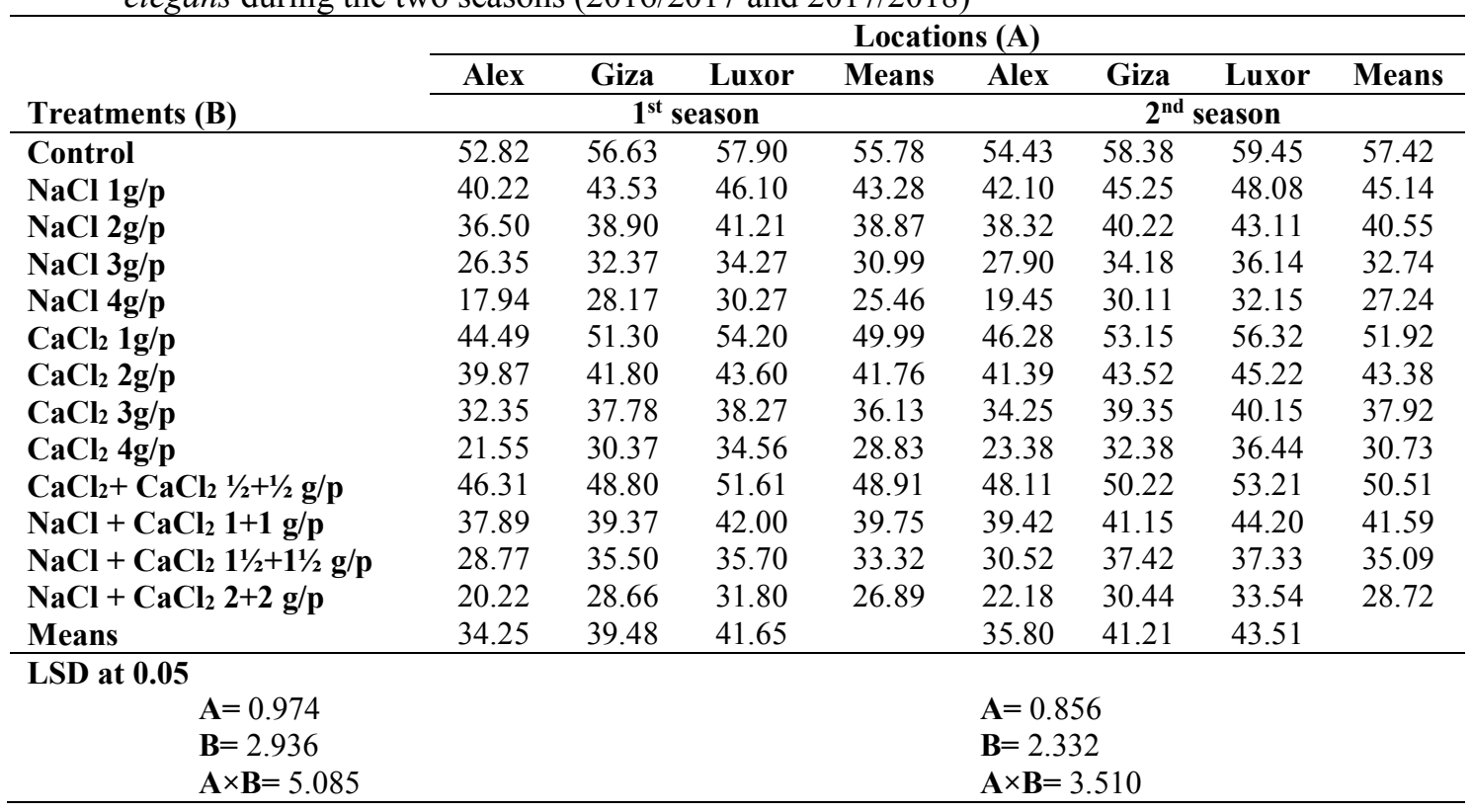

\section{b. Number of leaves/plant:}

It is evident from data outlined in Table (2) the great influence of growing plants under Luxor condition in both seasons for increasing number of leaves/plant. However, the lowest scores were a result of plants grown under Alexandria condition which occupied the third degree. Referring the effect of different salinity treatments plants treated with $\mathrm{NaCl}+\mathrm{CaCl}_{2} \frac{1 / 2}{2}+1 / 2 \mathrm{~g} /$ plant was the best treatments used for increasing number of leaves/plant. The interaction on the other side, show the great effect on plant grown at Luxor condition and treated with $\mathrm{CaCl}_{2}$ at $1 \mathrm{~g} / \mathrm{plant}$ for increasing number of leaves/plant in the two seasons.

\section{c. Number of branches/plant:}

Data presented in Table (3) showed the prevalence of planting under Luxor condition in raising numbers of branches/ plant. The increment of number of branches/ plant was also noticed for the effect of different salinity treatments as the treatment of $\mathrm{CaCl}_{2}$ at $1 \mathrm{~g} / \mathrm{plant}$ was the best treatment for elevating such parameter. In the matter of the interactions, data exhibited in Table (3) showed that plants grown under Luxor condition and treated with $\mathrm{CaCl}_{2}$ at $1 \mathrm{~g} /$ plant gave the highest records in both seasons. 
Table 2: Effect of different types of salinity under different locations on number of leaves/plant of Gypsophilla elegans during the two seasons (2016/2017 and 2017/2018).

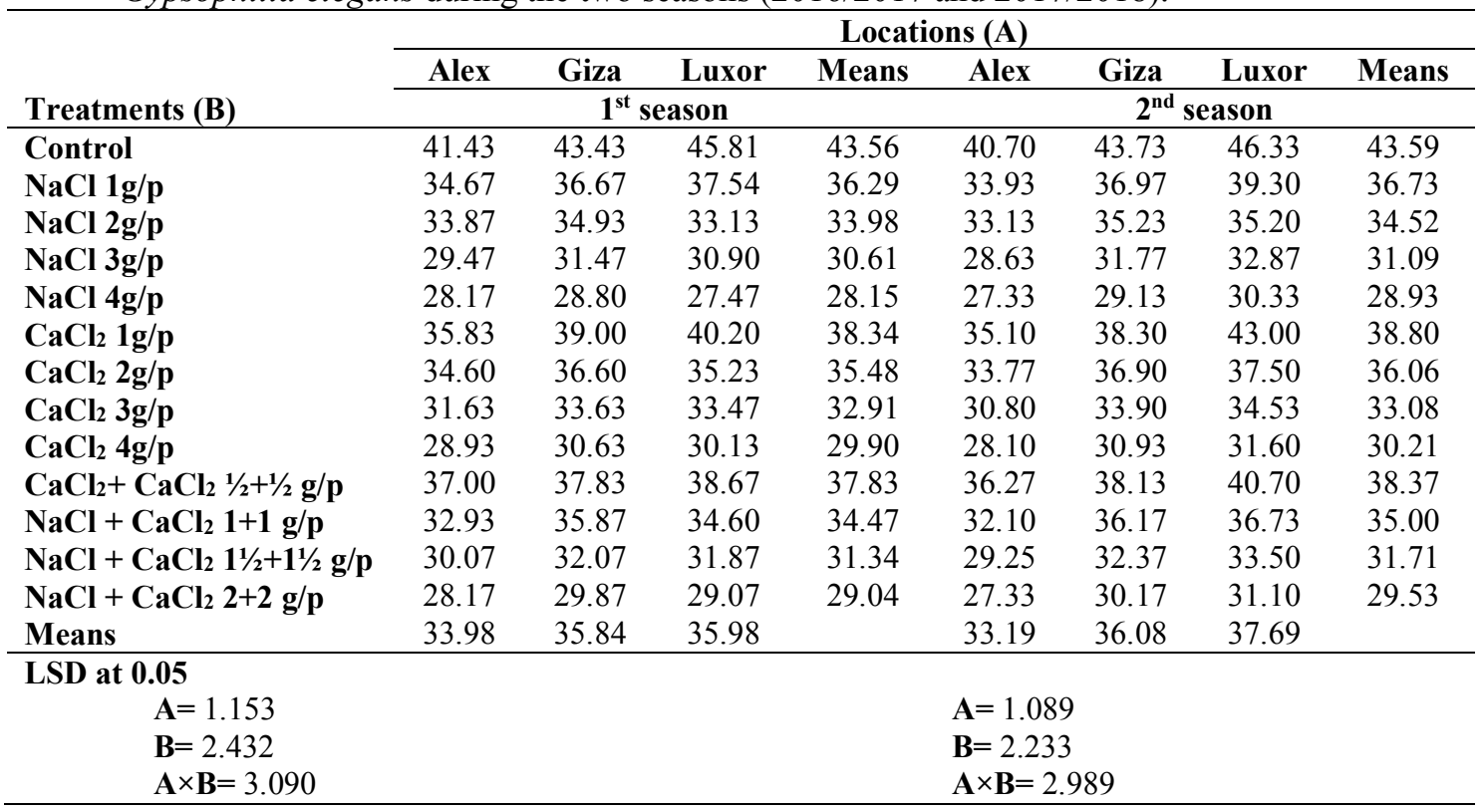

Table 3: Effect of different types of salinityunder different locationson number of branch/plant of Gypsophilla elegans during the two seasons (2016/2017 and 2017/2018)

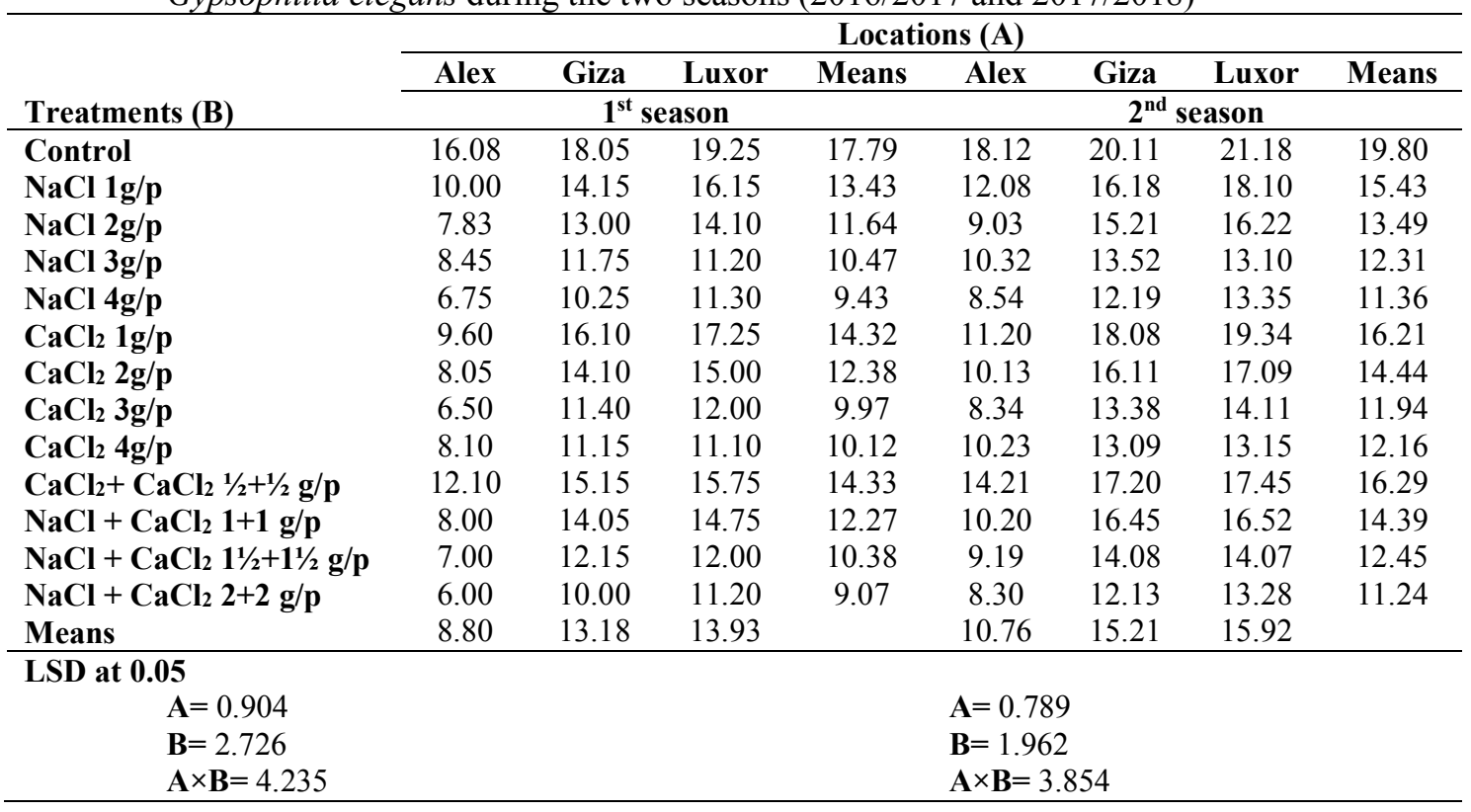

\section{d. Stem diameter (cm):}

As shown in Table (4) planting under Luxor condition proved its mastery in raising stem diameter in the two seasons. Regarding the effect of the different salinity treatments on stem diameter, plants treated with $\mathrm{CaCl}_{2}$ at $1 \mathrm{~g} /$ plant proved their mastery in raising stem diameter. Concerning the interaction, planting at Luxor condition and treated with $\mathrm{NaCl}$ at $1 \mathrm{~g} / \mathrm{plant}$ in the first season and those planted at Luxor condition and treated with $\mathrm{CaCl}_{2}$ at $1 \mathrm{~g} / \mathrm{plant}$ in the two seasons proved their superiority in raising stem diameter. 
Table 4: Effect of different types of salinityunder different locations on stem diameter $(\mathrm{cm})$ of Gypsophilla elegans during the two seasons (2016/2017 and 2017/2018)

\begin{tabular}{|c|c|c|c|c|c|c|c|c|}
\hline \multirow[b]{2}{*}{ Treatments (B) } & \multicolumn{2}{|c|}{ Locations (A) } & \multirow[b]{2}{*}{ Luxor } & \multirow[b]{2}{*}{ Means } & \multirow{2}{*}{\multicolumn{2}{|c|}{$\begin{array}{l}\text { Alex Giza } \\
2^{\text {nd }} \text { season }\end{array}$}} & \multirow[b]{2}{*}{ Luxor } & \multirow[b]{2}{*}{ Means } \\
\hline & & $1^{\text {st }}$ season & & & & & & \\
\hline Control & 0.52 & 0.57 & 0.75 & 0.61 & 0.49 & 0.64 & 0.78 & 0.64 \\
\hline $\mathrm{NaCl} 1 \mathrm{~g} / \mathrm{p}$ & 0.42 & 0.47 & 0.62 & 0.50 & 0.39 & 0.53 & 0.66 & 0.53 \\
\hline $\mathrm{NaCl} 2 \mathrm{~g} / \mathrm{p}$ & 0.44 & 0.46 & 0.54 & 0.48 & 0.41 & 0.50 & 0.60 & 0.50 \\
\hline $\mathrm{NaCl} 3 \mathrm{~g} / \mathrm{p}$ & 0.36 & 0.41 & 0.47 & 0.41 & 0.32 & 0.47 & 0.53 & 0.44 \\
\hline $\mathrm{NaCl} 4 \mathrm{~g} / \mathrm{p}$ & 0.41 & 0.38 & 0.35 & 0.38 & 0.38 & 0.55 & 0.48 & 0.47 \\
\hline $\mathrm{CaCl}_{2} \mathbf{1 g} / \mathbf{p}$ & 0.43 & 0.53 & 0.70 & 0.55 & 0.40 & 0.60 & 0.74 & 0.58 \\
\hline $\mathrm{CaCl}_{2} 2 \mathrm{~g} / \mathrm{p}$ & 0.46 & 0.51 & 0.60 & 0.52 & 0.42 & 0.57 & 0.67 & 0.55 \\
\hline $\mathrm{CaCl}_{2} 3 \mathrm{gg} / \mathrm{p}$ & 0.38 & 0.43 & 0.49 & 0.43 & 0.35 & 0.50 & 0.56 & 0.47 \\
\hline $\mathrm{CaCl}_{2} 4 \mathrm{~g} / \mathrm{p}$ & 0.42 & 0.40 & 0.43 & 0.42 & 0.38 & 0.47 & 0.52 & 0.46 \\
\hline $\mathrm{CaCl}_{2}+\mathrm{CaCl}_{2} 1 / 2+1 / 2 \mathbf{g} / \mathbf{p}$ & 0.48 & 0.48 & 0.67 & 0.54 & 0.45 & 0.55 & 0.71 & 0.57 \\
\hline $\mathrm{NaCl}+\mathrm{CaCl}_{2} 1+1 \mathrm{~g} / \mathrm{p}$ & 0.39 & 0.49 & 0.57 & 0.48 & 0.35 & 0.56 & 0.64 & 0.52 \\
\hline 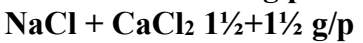 & 0.37 & 0.42 & 0.47 & 0.42 & 0.33 & 0.48 & 0.53 & 0.45 \\
\hline $\mathrm{NaCl}+\mathrm{CaCl}_{2} 2+2 \mathrm{~g} / \mathrm{p}$ & 0.41 & 0.39 & 0.41 & 0.40 & 0.38 & 0.46 & 0.50 & 0.43 \\
\hline Means & 0.44 & 0.47 & 0.57 & & 0.40 & 0.54 & 0.63 & \\
\hline \multicolumn{9}{|l|}{ LSD at 0.05} \\
\hline \multicolumn{5}{|l|}{$\mathbf{A}=0.125$} & \multicolumn{4}{|c|}{$\mathbf{A}=0.145$} \\
\hline \multicolumn{5}{|l|}{$\mathbf{B}=0.197$} & \multicolumn{4}{|c|}{$\mathbf{B}=0.209$} \\
\hline \multicolumn{5}{|l|}{$\mathbf{A} \times \mathbf{B}=0.289$} & \multicolumn{4}{|c|}{$\mathbf{A} \times \mathbf{B}=0.335$} \\
\hline
\end{tabular}

e. Fresh weight of leaves:

As shown in Table (5), the best planting location in raising fresh weight of leaves was Luxor location followed by Giza location in both seasons, but the lowest rates were due to its location at Alexandria. Concerning the effect of the different salinity treatments on such parameters the treatment of $\mathrm{CaCl}_{2}$ at $1 \mathrm{~g} /$ plant was the best treatment in raising fresh weight of leaves $(\mathrm{g})$ in the two seasons. The interaction on the other hand, revealed the superiority of planting under Luxor condition and treating with $\mathrm{CaCl}_{2}$ at $1 \mathrm{~g} /$ plant in the first season and of plant grown under Luxor condition and treated with $\mathrm{NaCl}+\mathrm{CaCl}_{2} \frac{1}{2}+1 / 2 \mathrm{~g} /$ plant in the second one.

Table 5: Effect of different types of salinity under different locations on fresh weight of leaves $(\mathrm{g})$ of Gypsophilla elegans during the two seasons (2016/2017 and 2017/2018)

\begin{tabular}{|c|c|c|c|c|c|c|c|c|}
\hline \multirow[b]{3}{*}{ Treatments (B) } & \multicolumn{8}{|c|}{ Locations (A) } \\
\hline & Alex & Giza & Luxor & Means & Alex & Giza & Luxor & Means \\
\hline & \multicolumn{4}{|c|}{$1^{\text {st }}$ season } & \multicolumn{4}{|c|}{$2^{\text {nd }}$ season } \\
\hline Control & 2.18 & 2.96 & 3.10 & 2.75 & 2.16 & 3.06 & 3.52 & 2.91 \\
\hline $\mathrm{NaCl} 1 \mathrm{~g} / \mathrm{p}$ & 1.63 & 2.54 & 2.31 & 2.16 & 1.61 & 2.64 & 2.78 & 2.34 \\
\hline $\mathrm{NaCl} 2 \mathrm{~g} / \mathrm{p}$ & 1.42 & 2.00 & 2.29 & 1.90 & 1.39 & 2.11 & 2.67 & 2.06 \\
\hline $\mathrm{NaCl} 3 \mathrm{~g} / \mathrm{p}$ & 1.02 & 1.75 & 1.96 & 1.58 & 1.00 & 1.86 & 2.62 & 1.83 \\
\hline $\mathrm{NaCl} 4 \mathrm{~g} / \mathrm{p}$ & 0.96 & 1.41 & 1.86 & 1.41 & 0.93 & 1.52 & 2.25 & 1.57 \\
\hline $\mathrm{CaCl}_{2} \mathbf{1 g} / \mathbf{p}$ & 1.92 & 2.79 & 2.95 & 2.55 & 1.90 & 2.88 & 2.34 & 2.37 \\
\hline $\mathrm{CaCl}_{2} 2 \mathrm{~g} / \mathrm{p}$ & 1.61 & 2.25 & 2.43 & 2.10 & 1.59 & 2.35 & 2.84 & 2.26 \\
\hline $\mathrm{CaCl}_{2} 3 \mathrm{~g} / \mathrm{p}$ & 1.14 & 1.93 & 2.16 & 1.74 & 1.12 & 2.03 & 2.55 & 1.90 \\
\hline $\mathrm{CaCl}_{2} 4 \mathrm{~g} / \mathrm{p}$ & 0.92 & 1.64 & 2.10 & 1.55 & 0.89 & 1.74 & 2.53 & 1.72 \\
\hline $\mathbf{C a C l}_{2}+\mathbf{C a C l}_{2} 1 / 2+1 / 2 \mathbf{g} / \mathbf{p}$ & 1.45 & 2.68 & 2.53 & 2.22 & 1.43 & 2.79 & 2.91 & 2.38 \\
\hline $\mathrm{NaCl}+\mathrm{CaCl}_{2} 1+1 \mathrm{~g} / \mathrm{p}$ & 1.37 & 2.14 & 2.36 & 1.96 & 1.34 & 2.24 & 2.75 & 2.11 \\
\hline 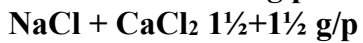 & 1.08 & 1.83 & 2.06 & 1.66 & 1.05 & 1.94 & 2.42 & 1.80 \\
\hline $\mathrm{NaCl}+\mathrm{CaCl}_{2} 2+2 \mathrm{~g} / \mathrm{p}$ & 0.78 & 1.51 & 1.90 & 1.40 & 0.72 & 1.59 & 2.32 & 1.54 \\
\hline Means & 1.46 & 2.22 & 2.41 & & 1.43 & 2.32 & 2.77 & \\
\hline \multicolumn{9}{|l|}{ LSD at 0.05} \\
\hline $\mathbf{A}=0.532$ & \multirow{2}{*}{\multicolumn{8}{|c|}{$\begin{array}{l}\mathbf{A}=0.452 \\
\mathbf{B}=0.633\end{array}$}} \\
\hline $\mathbf{B}=0.719$ & & & & & & & & \\
\hline $\mathbf{A} \times \mathbf{B}=1.274$ & & & & & \multicolumn{4}{|c|}{$\mathbf{A} \times \mathbf{B}=1.098$} \\
\hline
\end{tabular}




\section{f. Dry weight of leaves (g):}

Data registered in Table (6) show the superiority of planting at Luxor location in elevating dry weight of leaves in the two seasons, whereas, the condition of Alexandria gave the lowest means in this concern. Concerning the effect of the different salinity treatments on such parameters the treatment of $\mathrm{CaCl}_{2}$ at $1 \mathrm{~g} /$ plant proved its mastery in elevating dry weight of leaves $(\mathrm{g})$. The interaction on the other hand, indicated the prevalence of growing plants under Luxor condition with using the treatment of $\mathrm{NaCl}_{2}$ at $1 \mathrm{~g} /$ plant in the first season as well as those planted at Luxor and treated with $\mathrm{NaCl}_{2}$ at $1 \mathrm{~g} / \mathrm{plant}$ in raising dry eight of leaves in the second season.

Table 6: Effect of different types of salinity under different locations on dry weight of leaves (g) of Gypsophilla elegans during the two seasons (2016/2017 and 2017/2018)

\begin{tabular}{|c|c|c|c|c|c|c|c|c|}
\hline \multirow[b]{3}{*}{ Treatments (B) } & \multicolumn{8}{|c|}{ Locations (A) } \\
\hline & Alex & Giza & Luxor & Means & Alex & Giza & Luxor & Means \\
\hline & \multicolumn{4}{|c|}{$1^{\text {st }}$ season } & \multicolumn{4}{|c|}{$2^{\text {nd }}$ season } \\
\hline Control & 0.65 & 0.84 & 0.89 & 0.79 & 0.64 & 0.94 & 0.92 & 0.83 \\
\hline $\mathrm{NaCl} 1 \mathrm{~g} / \mathrm{p}$ & 0.26 & 0.65 & 0.75 & 0.55 & 0.26 & 0.75 & 0.76 & 0.59 \\
\hline $\mathrm{NaCl} 2 \mathrm{~g} / \mathrm{p}$ & 0.11 & 0.45 & 0.64 & 0.40 & 0.46 & 0.55 & 0.66 & 0.56 \\
\hline $\mathrm{NaCl} 3 \mathrm{~g} / \mathrm{p}$ & 0.08 & 0.38 & 0.48 & 0.32 & 0.08 & 0.49 & 0.54 & 0.37 \\
\hline $\mathrm{NaCl} 4 \mathrm{~g} / \mathrm{p}$ & 0.04 & 0.33 & 0.39 & 0.26 & 0.04 & 0.43 & 0.44 & 0.30 \\
\hline $\mathrm{CaCl}_{2} \mathbf{1 g} / \mathrm{p}$ & 0.20 & 0.78 & 0.83 & 0.60 & 0.19 & 0.88 & 0.87 & 0.65 \\
\hline $\mathrm{CaCl}_{2} 2 \mathrm{~g} / \mathrm{p}$ & 0.14 & 0.57 & 0.70 & 0.47 & 0.14 & 0.66 & 0.74 & 0.51 \\
\hline $\mathrm{CaCl}_{2} 3 \mathrm{gg} / \mathrm{p}$ & 0.05 & 0.48 & 0.55 & 0.36 & 0.05 & 0.53 & 0.60 & 0.39 \\
\hline $\mathrm{CaCl}_{2} 4 \mathrm{~g} / \mathrm{p}$ & 0.30 & 0.36 & 0.43 & 0.36 & 0.02 & 0.46 & 0.47 & 0.32 \\
\hline $\mathbf{C a C l}_{2}+\mathbf{C a C l}_{2} \frac{1 / 2+1 / 2}{\mathbf{g}} \mathbf{g} \mathbf{p}$ & 0.15 & 0.70 & 0.78 & 0.55 & 0.15 & 0.80 & 0.80 & 0.59 \\
\hline $\mathrm{NaCl}+\mathrm{CaCl}_{2} 1+1 \mathrm{~g} / \mathrm{p}$ & 0.08 & 0.50 & 0.66 & 0.41 & 0.07 & 0.60 & 0.69 & 0.45 \\
\hline $\mathrm{NaCl}+\mathrm{CaCl}_{2} 1 \frac{112}{2}+1^{1 / 2} / 2 / p$ & 0.02 & 0.42 & 0.49 & 0.31 & 0.02 & 0.51 & 0.54 & 0.36 \\
\hline $\mathrm{NaCl}+\mathrm{CaCl}_{2} 2+2 \mathrm{~g} / \mathrm{p}$ & 0.03 & 0.34 & 0.41 & 0.26 & 0.02 & 0.45 & 0.46 & 0.31 \\
\hline Means & 0.23 & 0.57 & 0.65 & & 0.24 & 0.66 & 0.69 & \\
\hline \multicolumn{9}{|l|}{ LSD at 0.05} \\
\hline $\mathbf{A}=0.235$ & & \multicolumn{7}{|c|}{$\mathbf{A}=0.209$} \\
\hline $\mathbf{B}=0.408$ & & \multicolumn{7}{|c|}{$\mathbf{B}=0.355$} \\
\hline $\mathbf{A} \times \mathbf{B}=0.630$ & & \multicolumn{7}{|c|}{$\mathbf{A} \times \mathbf{B}=0.523$} \\
\hline
\end{tabular}

\section{Flower parameters}

\section{a. Number of days from planting to flowering}

Data presented in Table (7) showed that planting under Luxor condition gave the lowest means of number of days from planting to flowering (day), whereas, the opposite was right for planting under Alexandria location in the two seasons in prolonging the time required from planting to flowering. The effect of the different salinity treatments on the time required from planting to flowering revealed the superiority of plants treated with $\mathrm{NaCl}_{2}$ at $4 \mathrm{~g} /$ plant in the first season and those treated with $\mathrm{CaCl}_{2}$ at $4 \mathrm{~g} / \mathrm{plant}$ in the second one for prolonging the time required from planting to flowering. The interaction on the other hand, clearly showed that planting under the condition of Alexandria and treated with $\mathrm{CaCl}_{2}$ at $4 \mathrm{~g} / \mathrm{plant}$ in the first season and those grown at the same condition (Alexandria) and treated with $\mathrm{NaCl}$ $4 \mathrm{~g} / \mathrm{plant}$ in the second one in increasing the time required from planting to flowering.

\section{b. Number of flowers/plant}

In both seasons, Luxor condition proved its mastery in raising number of flowers/plant against the other locations used in the current study. The effect of the different salinity treatments on number of flowers/plant was clear as the treatment of $\mathrm{NaCl}_{2}+\mathrm{CaCl}_{2}$ at $1 / 2+1 / 2 \mathrm{~g} /$ plant proved its superiority in raising number of flowers/plant. The interaction, on the other side, between $\mathrm{CaCl}_{2}$ at $1 \mathrm{~g} / \mathrm{plant}$ under Luxor condition in the first seasons or $\mathrm{NaCl}_{2}+\mathrm{CaCl}_{2}$ at $1 / 2+1 / 2 \mathrm{~g} /$ plant under Luxor condition in the second one proved their superiority in raising number of flowers/plant. 
Table 7: Effect of different types of salinity under different locations on number of days from planting to flowering (day) of Gypsophilla elegans during the two seasons (2016/2017 and 2017/2018)

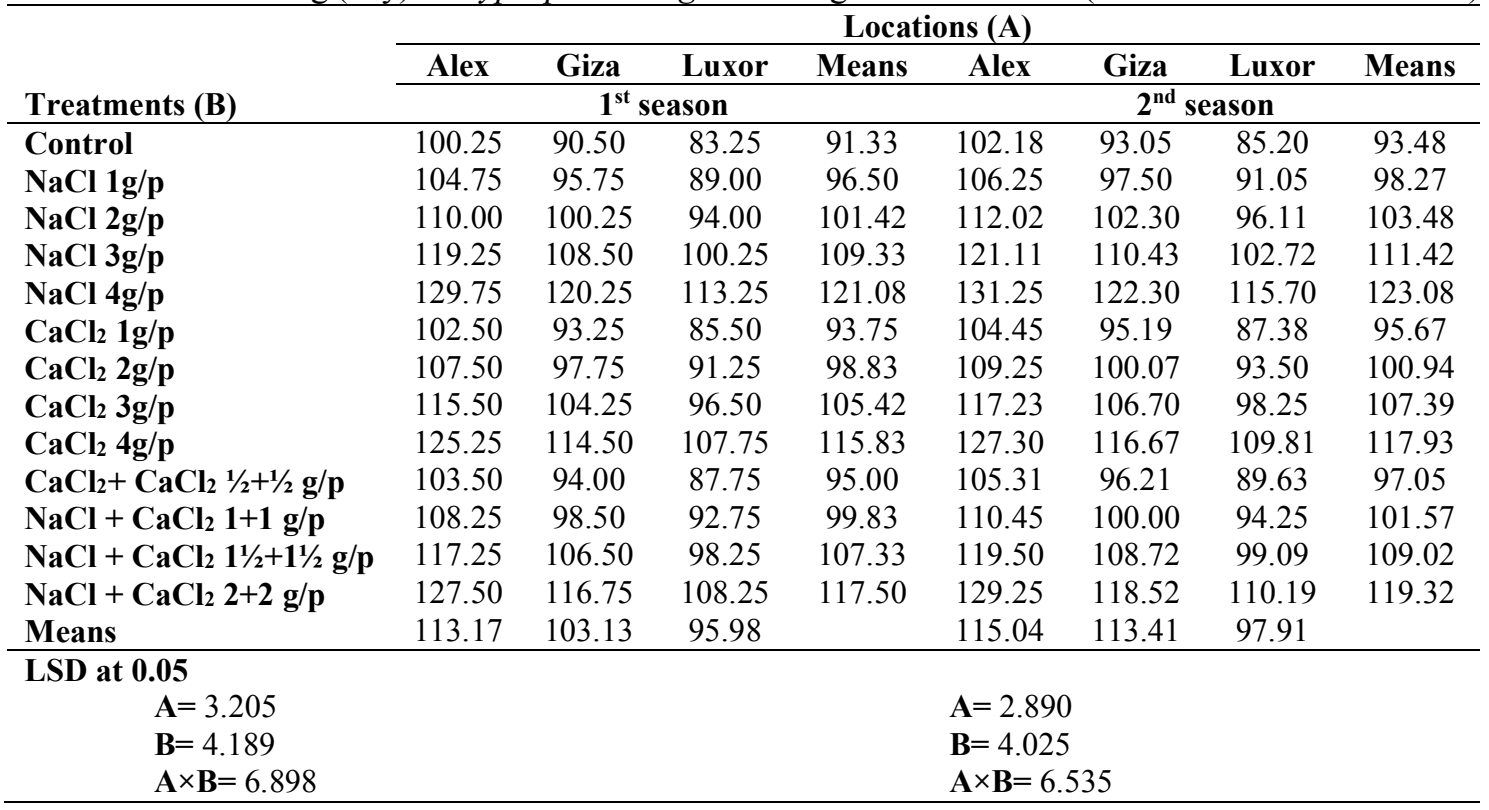

Table 8: Effect of different types of salinity under different locations on number of flowers/ plant of Gypsophilla elegans during the two seasons (2016/2017 and 2017/2018)

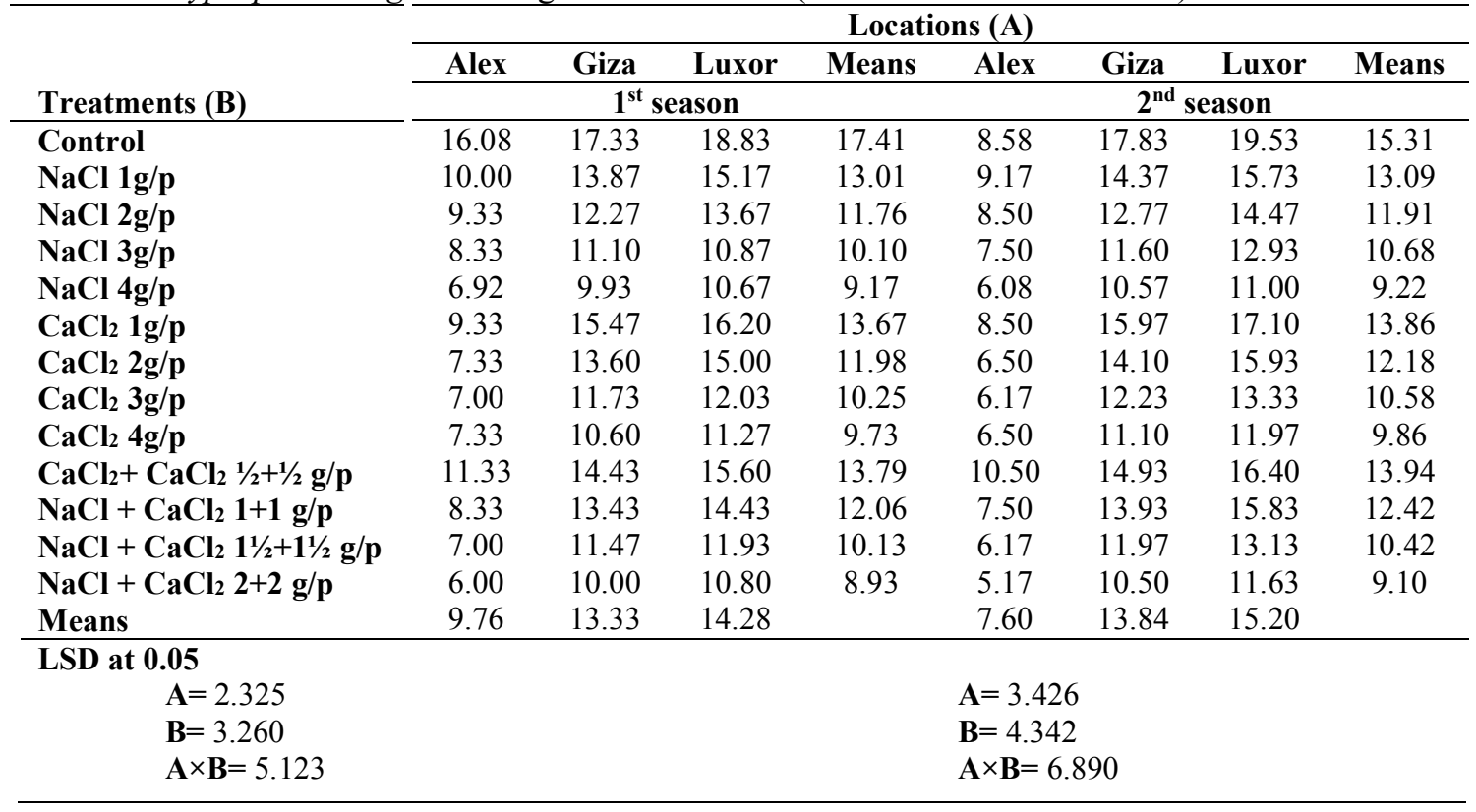

c. Flower diameter (cm.)

As shown from data outlined in Table (9), Luxor location was the best planting location in raising flower diameter in the two seasons, with insignificant effect in both seasons. With respect to the effect of the different salinity treatments, the treatment of $\mathrm{CaCl}_{2}$ at $1 \mathrm{~g} /$ plant in the first season and $\mathrm{NaCl}_{2}+\mathrm{CaCl}_{2}$ at $1 / 2+1 / 2 \mathrm{~g} / \mathrm{plant}$ in the second one gave the highest values in both seasons, with insignificant effect in both seasons. The interaction, showed that plants grown under Luxor condition and treated with $\mathrm{NaCl}_{2}+$ $\mathrm{CaCl}_{2}$ at $1 / 2+1 / 2 \mathrm{~g} /$ plant in the first season and those grown in Luxor location in the second one and treated with $\mathrm{CaCl}_{2}$ at $1 \mathrm{~g} /$ plant was the best treatments for increasing flower diameter. 
Table 9: Effect of different types of salinity under different locations on flower diameter $(\mathrm{cm})$ of Gypsophilla elegans during the two seasons (2016/2017 and 2017/2018)

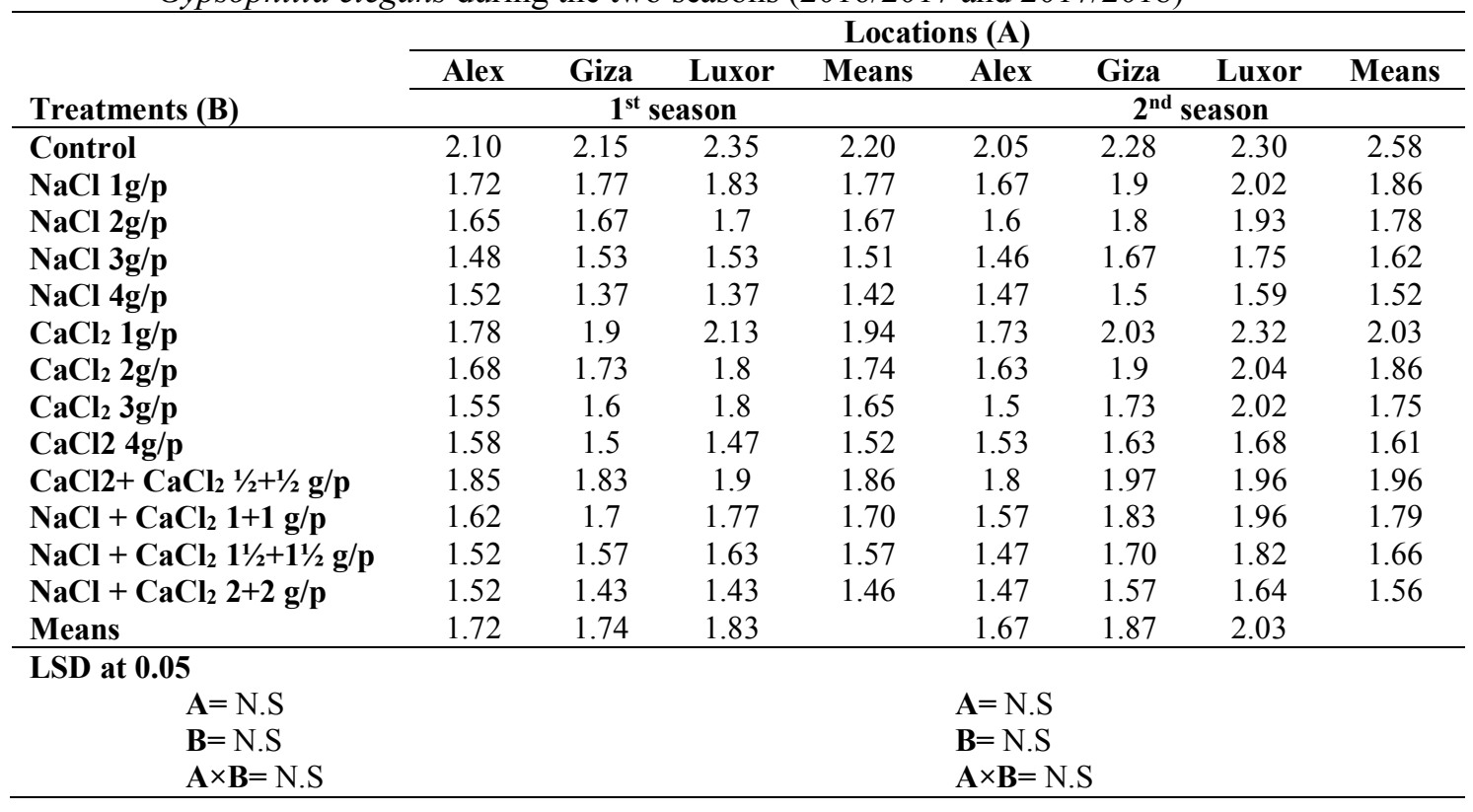

\section{Effect on chemical constituents}

a. Chlorophyll a (mg/g f.w.)

Obviously, data illustrated in Figure (1) proved the superiority of Luxor locations in increasing chlorophyll a (mg/g f.w.) in the leaves comparing with that gained from the other location. Concerning the effect of the different salinity treatments the treatment of $\mathrm{CaCl}_{2}$ at $1 \mathrm{~g} /$ plant increased chlorophyll a (mg/g f.w.) comparing with that gained from the other treatments. In the matter of interaction, plants grown underLuxor condition and treated with $\mathrm{CaCl} 2$ at $1 \mathrm{~g} /$ plant proved their superiority in increasing chlorophyll a content in the leaves in both seasons.

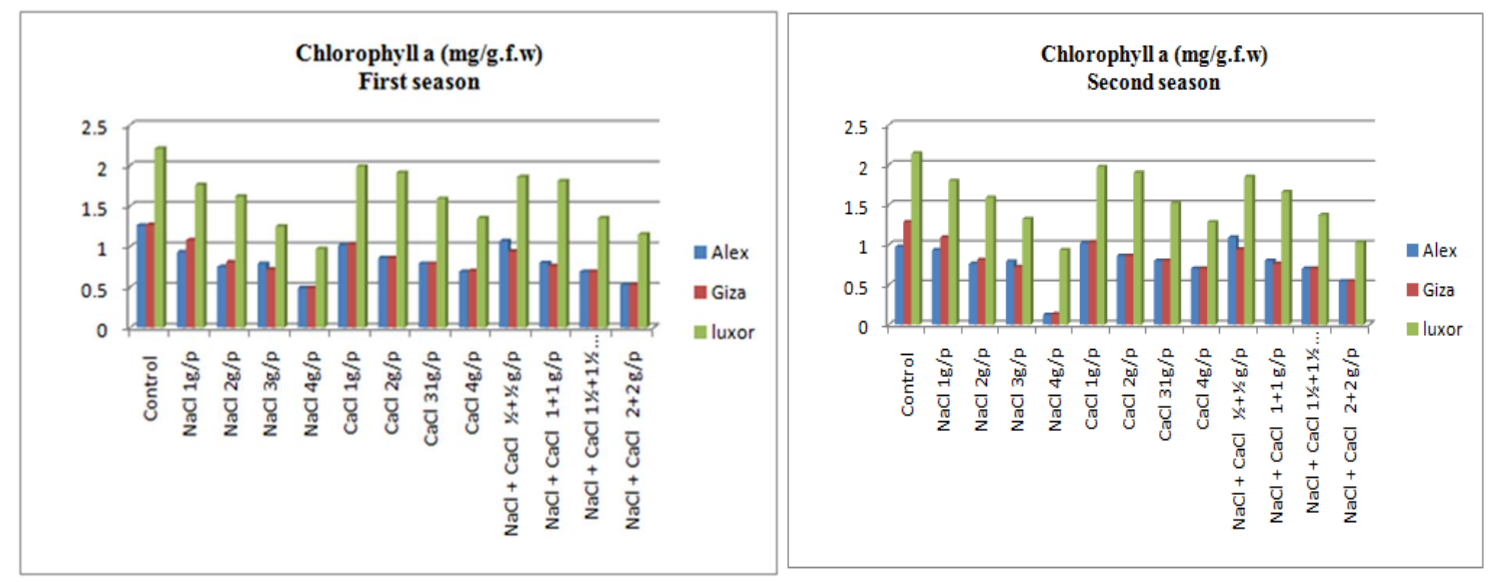

Fig. 1: Effect of different types of salinity under different locationson chlorophyll a of Gypsophilla elegans during the two seasons (2016/2017 and 2017/2018)

\section{b. Chlorophyll b (mg/g f.w.)}

Data illustrated in Figure (2) indicated the prevalence of Luxor location in producing the highest values of chlorophyll $\mathrm{b}(\mathrm{mg} / \mathrm{g}$ f.w.) in the leaves in both seasons, followed in the second category by Giza location and then of Alexandria location. On the other hand, and regarding to the effect of the different salinity treatments on chlorophyll b content, data outlined in Figure (2) show the prevalence of the treatment of $\mathrm{CaCl}_{2}$ at $1 \mathrm{~g} /$ plant for increasing the content of chlorophyll $\mathrm{b}$ in the leaves in both 
seasons. The interaction, on the other side, showed the great influence of plants grown under Luxor condition and treated with $\mathrm{CaCl}_{2}$ at $1 \mathrm{~g} /$ plant for increasing chlorophyll $\mathrm{b}$ in the leaves in the two seasons.
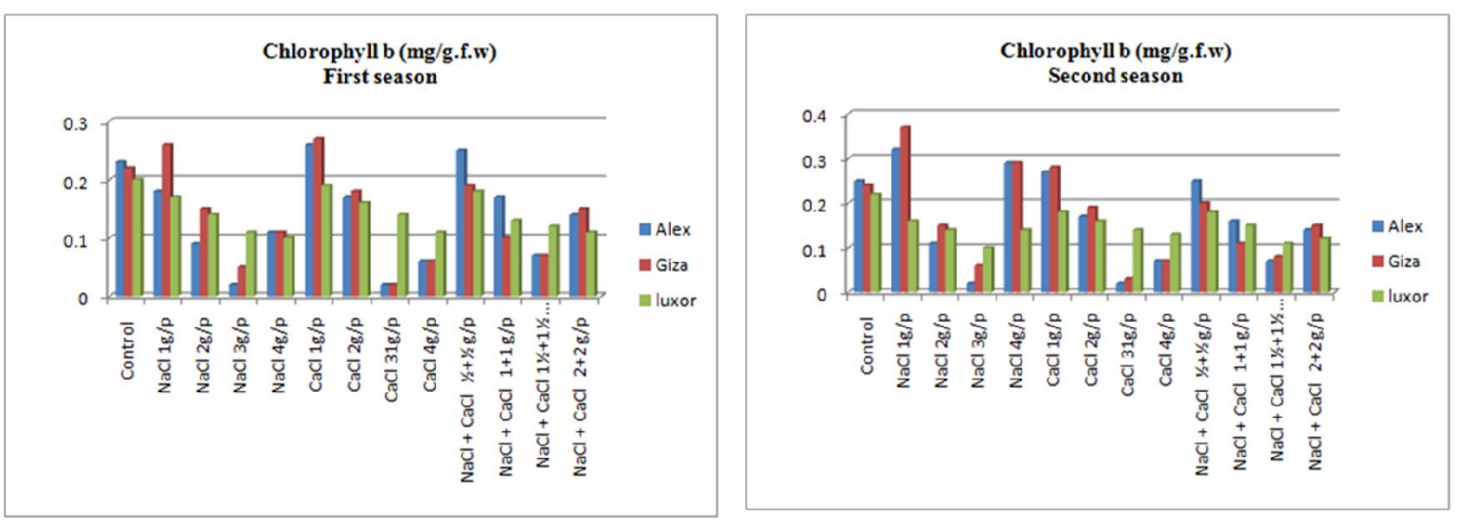

Fig. 2: Effect of different types of salinity under different locations on chlorophyll b of Gypsophilla elegans during the two seasons (2016/2017 and 2017/2018)

\section{c. Carotenoids}

As shown from data illustrated in Figure (3), Luxor location was the best for increasing the content of carotenoids in the leaves in both seasons, followed in the second rank by that obtained from Giza location. However, the least scores were obtained from Alexandria location. On the other hand, the treatment of $\mathrm{CaCl}_{2}$ at $1 \mathrm{~g} /$ plant proved its mastery in producing the highest values of carotenoids content in the leaves comparing with that obtained from the other salinity treatments in the two seasons. The interaction indicated the superiority of plants grown under Luxor condition and treated with $\mathrm{CaCl}_{2}$ at $1 \mathrm{~g} /$ plant in both seasons.
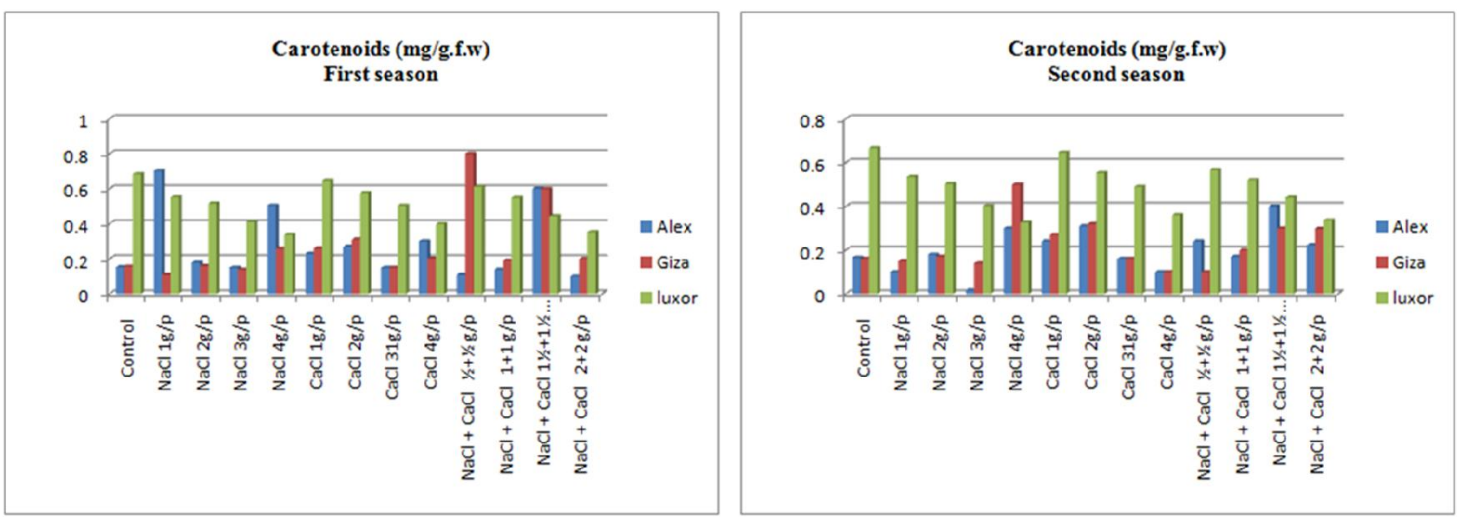

Fig. 3: Effect of different types of salinity under different locations on carotenoids of Gypsophilla elegans during the two seasons (2016/2017 and 2017/2018).

\section{d. Proline (mg/100g f.w.):}

Data illustrated in Figure (4) showed the great influence of Alexandria location in raising the content of proline, comparing with that gained from the other locations in both seasons. Concerning the effect of the different salinity treatments, it is obvious that the treatment of $\mathrm{NaCl}_{2}$ at $4 \mathrm{~g} / \mathrm{plant}$ was the best in raising proline content in the leaves in both seasons. In the matter of the interaction, plants grown under Alexandria location and treated with $\mathrm{NaCl}_{2}$ at $4 \mathrm{~g} / \mathrm{plant}$ gave the highest value of proline in both seasons comparing with that gained from the other treatments. 

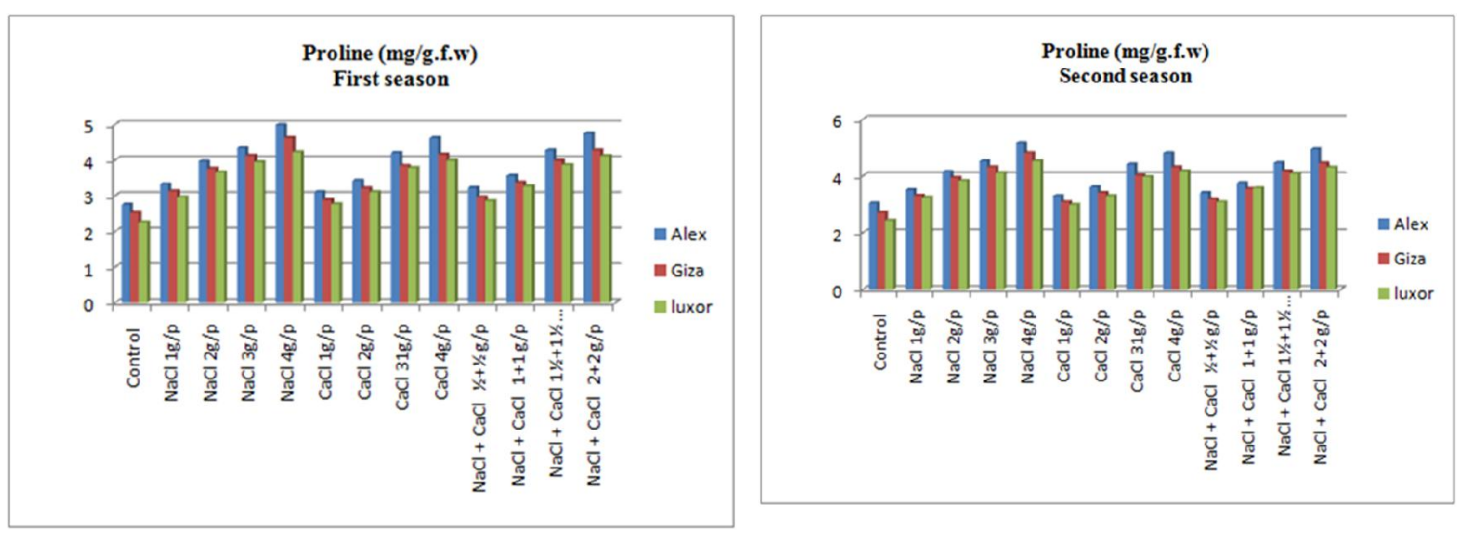

Fig. 4: Effect of different types of salinity under different locations on proline of Gypsophilla elegans during the two seasons $(2016 / 2017$ and 2017/2018)

\section{Discussion}

The previous results are in agreement with the findings of many authors on other plants (Mass 1984; Sonneveld and Van Der Burg 1991; Sonneveld et al., 1999). Also, Arshi et al., 2002) used many concentration of $\mathrm{NaCl}$ such as $0,40,80,120$ and $160 \mathrm{mM}$ on senna plants and concluded that, the different $\mathrm{NaCl}$ concentrations caused a pronounced reduction in total chlorophyll content, whereas proline in the leaves was markedly increased. Koskal et al. (2010) studied the effects of saline irrigation levels on flowering and flower quality in a soilless of Freesia hybrids (Obren, Athena and Cordula varieties) planted in plastic greenhouse under Mediterranean conditions). Four salinity levels $\mathrm{EC}_{1}=1.5$ $\mathrm{dSm}^{-1}$ (Control), $\mathrm{EC}_{2}=3.0 \mathrm{dSm}^{-1}, \mathrm{EC}_{3}=4.5 \mathrm{dSm}^{-1}$ and $\mathrm{EC}_{4}=6.0 \mathrm{dsm}^{-1}$ were applied using $\mathrm{NaCl}$. It was found that saline irrigation water levels decreased flower yield, flower stem length and diameter, flower number and flower spike length in all freesia varieties studied. El-Fouly et al (2015) on Iris tingitanacv, Wedgewood treated with different salinity levels $(0,1000,2000$ and $4000 \mathrm{ppm})$ reported that vegetative growth height, number of leaves/plant, inflorescence, stem length and diameter were gradually decreased with increasing salinity level. Abdel-Said (2017) on Vincarosae, L. concluded that the result of the effect of salinity on plant parameters revealed that all vegetative growth parameters (vegetative growth height), all rooting parameters (root length, fresh and dry weight) and either number of flowers and branches/plant, where all the above mentioned traits were decently decreased by raising salinity level.

Regarding the effect of the different planting locations on morphological characters and chemical constituents of the plant a lot of scientists studied the effect of different planting locations on various plants species under Egyptian condition.

\section{References}

Arshi, A.A. and M. Iqbal, 2002. Growth and Metabolism of Senna as affected by salt stress Biologic Plant Arum, 45(L.): 295-298.

Abdel-Said, 2017. Response of Vinca rosae, L. Don (Catharanthus roseus, L.) plant different irrigation and salinity levels

Bates, L.S., R.P. Waldern, and L.D. Tear, (1973) Rapid determination of free proline under water stress. Plant and Soil, 39: 205 - 207.

BMCA, 2015. Aggressive ornamental databas: baby's breath British Columbia, Ministry of Agriculture. Victoria, British Columbia, Canada.

http://www.zgov. baaca.ca.assests/gov/environment/plants-animals-and-ecosystems/ invasivecontrolled-species/terrestrial-plants-pdfs/baby's breath. (Accessed January 31, 2019)

Darwent, A.L., 1975. The biology of Canadian weeds Gypsophila paniculata, L. Canadian Journal of Plant Sciences, 55: 1049 - 1058. 
Koksal, A., T. Akin, and B. Dursun, 2016. Effect of saline irrigation, water applications on quality characteristics of Freesia grown in greenhouse Akdeniz Universities ZirratFacul Tess Oergisi, 23(1): 41-46.

Mass, E., 1984. Crop tolerance California Agriculture, 38: 20 - 24.

Pringle, J.S., 2005. Gypsophila p 153 - 156 in Flora of North America Editorial Committer (eds). Flora of North America of Mexico Vol. 5: Magnoliophyta: Caryophyllidae part 2 Oxford University Press, New York, NY.

Saric, M., R. Kastrori, R. Curci, T. Capina, and I. Gerie, (1967) Chlorophyll determination Univ. Unoveu Sadu Parktikum is Fizologize Bibjoke, Beagard, Haunca, Anjiga, 215.

SAS program, 1994. SASISTAT User's Guide; Statistics. Vers. 6. 04. $4^{\text {th }}$ Ed., SAS Institute Inc., Cary. N. C., U.S.A.

Snedecor, G.W. and W.G. Cochoran, 1980. Statistical Methods, $6^{\text {th }}$ ed. Iowa State Univ. Press. Ames Iowa U.S.A.

Sonneveld, C. and Ven Der Burg, 1991. Chlorid salinity in fruit vegetative crops in soilless culture Journal of Agriculture Science, 39: 112 - 115.

Sonneveld, C., R. Bass, and J. De Hoog, 1999. Salt tolerance of flower crop grown in soilless culture. Journal of Plant Nutrition, 22: 1033 - 1048. 